\title{
Occurrence of Breast Cancer in the Population of Peri- and Postmenopausal Women in the Aspect of Environmental Exposure to Airborne Dust Pollution
}

\author{
Aleksandra Duda ${ }^{1}$, Agata Piekut ${ }^{2}$, Małgorzata Ćwieląg-Drabek ${ }^{2 *}$ \\ ${ }^{1}$ Doctoral School of the Medical University of Silesia in Katowice (Poland), \\ 15 Poniatowskiego Street, 40-055 Katowice, Poland \\ ${ }^{2}$ Department of Environmental Health, Faculty of Health Sciences in Bytom, Medical University \\ of Silesia in Katowice (Poland), 18 Piekarska Street, 41-902 Bytom, Poland
}

Received: 17 November 2020

Accepted: 8 March 2021

\begin{abstract}
Breast cancer (C50) is the most frequently diagnosed cancer in women and the leading cause of their death worldwide. In 2018, the IARC estimated the number of new cancer cases worldwide at 18.1 million and 9.6 million deaths caused by them. C50 is a disease that is most often the result of the interdependence of personal genetic predispositions and hormonal conditions as well as the lifestyle maintained in the surrounding environment, which is directly or indirectly related to the disease. The main aim of the study was to analyze the correlation between the level of airborne dust pollutants and the incidence of C50 in the population of peri- and postmenopausal women living in cities with county rights in the Silesia Province, Poland, in the years 2015-2018. The significant differentiation of C50 incidence rates in peri- and postmenopausal women in 19 cities in the Silesia Province indicates the existence of environmental determinants of the carcinogenic process. Studies have shown clear differences in the number of new cases of $\mathrm{C} 50$ reported in the population of women over 45 years of age by the National Cancer Registry and the National Health Fund, which demonstrates the limitations of the healthcare management system.
\end{abstract}

Keywords: breast cancer, morbidity, dust pollution, territorial diversity

*e-mail: mdrabek@sum.edu.pl 


\section{Introduction}

Breast cancer (malignant breast cancer, C50) is the most frequently diagnosed cancer in women and the leading cause of their death worldwide. In 2018, the International Agency for Research on Cancer (IARC) estimated the number of new cancer cases worldwide at 18.1 million and 9.6 million deaths caused by them. Among them, 2.1 million new cases of breast cancer were diagnosed in women, which globally accounted for 1 in 4 cases of all diagnosed malignancies among women in 2018. This disease entity, with still mostly unknown causes, is the most frequently diagnosed in the vast majority of countries - in 154 out of 185 countries, and the leading cause of death in over 100 countries $[1,2]$.

GLOBOCAN data, from the year 2018, showed the highest incidence of breast cancer among women in Australia and New Zealand (94.2/100,000). In Western Europe, e.g. in Belgium, the highest rates of breast cancer incidence in the world are recorded, exceeding 113/100,000 women, with their occurrence in neighboring countries at the level of 92.6/100,000 women (Netherlands, France). In Northern European countries, such as Great Britain, Sweden, Finland and Denmark, only slightly lower rates are recorded (90.1/100,000 women), slightly fewer cases are observed in North America (USA, Canada) - 84.8/100,000 women, and then in the countries of Southern Europe (e.g. Italy) - 80.3/100,000 women. In the countries of Eastern Europe, the incidence rates oscillate around $54.5 / 100,000$ women, similar to the countries of South America (56.8/100,000 women). Globally, the lowest incidence of breast cancer in women is in African countries (27.9-37.3/100,000 women) and in southcentral Asia (25.9/100,000 women) [1].

Breast cancer is the most common form of malignant neoplasm also in the female population in Poland, where in the last century it has become one of the main causes of premature mortality in women. Since the mid-1970s, it accounts for more than 1 in 5 cases of malignant neoplasms and is now diagnosed in over 18,000 women annually. Women who contracted C50 in the first decade of the $21^{\text {st }}$ century lose on average about 4 years of life [3].

In 2017, the percentage of new cases of breast cancer in the Polish population accounted for $22.5 \%$ of the total number of cancer cases, and the incidence was 91/100,000 women. This share has remained at a similar level for several years, fluctuating slightly [4]. The mortality rate from breast cancer in 2017 was $14.8 \%$, similar to previous years. The highest share among the most common cause of cancer deaths of women had cancer of the lung (17.4\%), wherein the proportion of deaths due to breast cancer increases slightly every year - $2015(14.1 \%)[4,5]$.

The peri- and postmenopausal period is the time of increased oncological risk in women, often burdened with comorbidities. The scientific achievements to date, determining the basis of the development of breast cancer, allowed to observe factors predisposing the occurrence of this type of cancer in a specific population of women. Specifying the risk factors and determining the circumstances of their occurrence allowed for typing the risk of the incidence of breast cancer. The fact that a given person belongs to a population with an increased risk of carcinogenesis is not synonymous with the development of the disease, but it allows for taking preventive steps in order to exclude or at least limit inappropriate, often erroneous behaviors in everyday life habits, that may initiate the neoplastic process. Breast cancer is a disease caused by many factors that directly influence neoplasm in the area of the breast gland. Usually it is the result of the occurrence of several of them. Among all the features predisposing to breast cancer, gender is the most important because women have this cancer 100 times more often than men [6]. Age is also a key determinant of neoplasm in the mammary gland; the risk of the disease doubles in every decade of life until the menopause [3]. In Poland, most cases of breast cancer occur in women over 50, estimating the incidence rate in this population group at over $80 \%$ of all cases of breast cancer [5].

Breast cancer is a disease that is most often the result of the interdependence of personal genetic predispositions and hormonal conditions as well as the lifestyle maintained in the surrounding environment, which is directly or indirectly related to the disease. Over the past decade, genetic factors have been attributed a $5-10 \%$ share in the development of breast cancer, more and more research has focused on exposure to environmental pollutants, assessing their contribution to cancer at the level of $30 \%$ or even $50 \%$. In the case of breast cancer, especially during the development of the mammary gland, the time of exposure to carcinogenic compounds and lifestyle are a key role, as the increased risk occurs among people with a defective process of detoxification of carcinogenic xenobiotics made from chemical compounds, ubiquitous in both the external and internal environment life of a woman [7]. Estrogen oxidative catabolism, mediated by cytochrome P450 enzymes, generates reactive free radicals that can cause oxidative damage. The same enzymes as estrogenic metabolic pathways catalyze the activation of many xenobiotics, which exert pathological effects by producing reactive free radicals. Hence, such an important role in the development of breast cancer is played by the balance between phase I (carcinogen activation system) and phase II (detoxification) [8]. Environmental estrogens can induce tissue specific, time and dose dependent estrogenic or anti-estrogen responses. Their impact on neoplasm development in the mammary gland depends in particular on the intensity and duration of exposure to these compounds during the developmental stages of the mammary glands, which are extremely sensitive to hormone levels [7]. Particulate emissions are by far the main ground of air pollution, especially in urban 
agglomerations, which include a whole range of agents with high carcinogenic potential, with PAHs in the first place. In the atmospheric air and in the dust occurring in confined spaces, a number of chemical substances were identified, included in the group of the so-called Endocrine Disruptors (EDs) - endocrine disrupting compounds which mimic or antagonize the action of endogenous estrogens (e.g. phthalates, bisphenol A, polychlorinated biphenyls - PCBs) [7,9]. There are scientific evidence that air pollution is associated with the increased incidence of cancer and the mortality of the female population suffering from breast cancer [9]. Exposing the female population to excessively high concentrations of particulate matter is an important factor affecting their health condition. In 2013, the International Agency for Research on Cancer classified outdoor air pollution and particulate matter as a human carcinogen (Group I), especially the fraction with a diameter smaller than or equal to $2.5 \mu \mathrm{m}$ increases the risk of cancer development [10]. Extensive research suggests that environmental exposure to air pollution, combined with genetic predisposition, age and hormone exposure, has a cumulative effect on an increased risk of breast cancer. Limiting the exposure of the female population to carcinogens both in the workplace, in the place of residence and in the surrounding environment may be the most important element of a comprehensive breast cancer prevention strategy. It would be desirable to rigorously test all new chemicals put into use for potential estrogenic activity [7].

The main aim of the study was to analyze the correlation between the level of airborne dust pollutants and the incidence of breast cancer (C50) in the population of peri- and postmenopausal women living in cities with county rights in the Silesia Province, Poland, in the years 2015-2018. The detailed objectives were the analysis of differences between the incidence rates of women in the peri- and postmenopausal age, calculated on the basis of data obtained from the National Health Fund and the National Cancer Registry, and the impact of long-term exposure to dust pollution $\left(\mathrm{Cd}, \mathrm{PM}_{10}, \mathrm{BaP}, \mathrm{PCDD}\right.$ and PCBs$)$ on the incidence of $\mathrm{C} 50$ in the studied population of women.

\section{Material and Methods}

The research material consisted of data on the number of malignant breast cancer cases in the population of women in peri- and postmenopausal age (aged 45 years or more), in cities with county rights of the Silesia Province, in 2015-2018. The data came from the records of the National Health Fund (NHF) and the National Cancer Registry (NCR). In order to obtain the data necessary for the analysis, applications were made to the NHF and the NCR in November 2019. At that time, the National Health Fund had data up to 2018 and the NCR up to 2017. In order to estimate the trend of the occurrence of C50 in the population of women aged $45+$, it was decided to compile data from the same time intervals (3 years). Therefore, data from the NHF for 2016-2018, and from the NCR from 2015-2017 were obtained. On the other hand, the analysis of data, taking into account the source of their obtaining, was made by comparing the data from the same two years, i.e. 2016-2017. The source of data on the number of women living in cities with county rights in the Silesia Province in 2015-2018 was the Central Statistical Office (CSO). Long-term data on dust pollution were also collected from the reports of the Provincial Sanitary and Epidemiological Station in Katowice. They included such pollutants as: $\mathrm{Cd}, \mathrm{PM}_{10}$, $\mathrm{BaP}$. For the purposes of this study, the Department of Environmental Health, operating as part of the Faculty of Health Sciences of the Medical University of Silesia in Katowice, made available the average concentrations of dioxins (PCDDs), furans (PCDFs) and polychlorinated biphenyls (PCBs) determined in the selected cities with county rights of the Silesia Province.

Based on the data obtained from the NHF, NCR and $\mathrm{CSO}$, the crude morbidity rates of breast cancer per 100,000 women were calculated in each particular year of the analyzed period, in 19 cities with county rights in the Silesia Province, in order to present trends in the incidence of C50 in the Upper Silesia, noted by NHF and NCR.

In order to analyze the correlation between the incidence rates in the population of women in periand postmenopausal period in the cities with county rights in Silesia Province, recorded by the NCR and the NHF, and the average concentrations of airborne dust pollutants in their area, a statistical analysis was performed examining the relationship between the various variables:

- the mean value of C50 incidence rates in the studied group of women registered by the National Cancer Registry, amounting to $177.0 \pm 36.9$, and the median measurement of benzo (a) pyrene concentration in the air, equal to $31.9 \mathrm{ng} / \mathrm{m}^{3}$,

- the mean value of C50 incidence rates in the studied group of women who received services recorded in the National Health Fund, amounting to $368.0 \pm 42.0$, and the median measurement of benzo(a)pyrene concentration in the air, equal to $31.9 \mathrm{ng} / \mathrm{m}^{3}$,

- the mean value of C50 incidence rates in the studied group of women registered by the National Cancer Registry, amounting to $177.0 \pm 36.9$, and the median value of cadmium concentration in the air, equal to $4 \mathrm{ng} / \mathrm{m}^{3}$,

- the mean value of C50 incidence rates in the studied group of women who received services recorded by the National Health Fund, amounting to $368.0 \pm 42.0$, and the median value of cadmium concentration in the air, equal to $4 \mathrm{ng} / \mathrm{m}^{3}$,

- the mean value of the C50 incidence rates in the studied group of women listed in the National Cancer Registry, amounting to $177.0 \pm 36.9$, and the 
median measurement of the concentration of PM10 suspended dust in the air, equal to $82.9 \mu \mathrm{g} / \mathrm{m}^{3}$,

- the mean value of the $\mathrm{C} 50$ incidence rates in the studied group of women who received services registered with the National Health Fund, amounting to $368.0 \pm 42.0$, and the median of the concentration of suspended dust $\mathrm{PM}_{10}$ fraction in the air, equal to $82.9 \mu \mathrm{g} / \mathrm{m}^{3}$,

- the mean value of C50 incidence rates in the studied group of women registered by the National Cancer Registry, amounting to $177.0 \pm 36.9$, and the average concentration of dioxins and furans (PCDD/Fs) in the air, equal to $109.8 \pm 25.8 \mathrm{fg} \mathrm{I}-\mathrm{TEQ} / \mathrm{m}^{3}$,

- the mean value of C50 incidence rates in the studied group of women who received services registered with the National Health Fund, amounting to $368.0 \pm 42.0$, and the average concentration of dioxins and furans (PCDD/Fs) in the air, equal to $109.8 \pm 25.8$ fg I- TEQ $/ \mathrm{m}^{3}$,

- the mean value of C50 incidence rates in the study group of women registered by the National Cancer Registry, amounting to $177.0 \pm 36.9$, and the median concentration of polychlorinated biphenyls (PCBs) in the air, equal to $5.4 \mathrm{fg} \mathrm{I}-\mathrm{TEQ} / \mathrm{m}^{3}$,

- the mean value of $\mathrm{C} 50$ incidence rates in the studied group of women who received services registered with the National Health Fund, amounting to $368.0 \pm 42.0$, and the median concentration of polychlorinated biphenyls ( $\mathrm{PCBs}$ ) in the air, equal to $5.4 \mathrm{fg} \mathrm{I}-\mathrm{TEQ} / \mathrm{m}^{3}$.

In order to analyze the correlation between the female breast cancer incidence rates and the level of airborne dust pollutants, the following statistical tests were used:

- descriptive statistics,

- Shapiro-Wilk normality tests,

- Pearson's linear correlation coefficient,

- Spearman's rank correlation coefficient,

- multiple regression.

Statistical calculations were performed in the Statistica 13.3 program. The adopted level of significance was $\mathrm{p}=0.05$.

\section{Results and Discussion}

When analyzing the rates of breast cancer incidence in women according to the data obtained from the National Health Fund, in individual cities of the Silesia Province in 2016-2018, their wide variation is noticeable. The highest values of the incidence rate in 2016 were recorded in Tychy (463.9/100,000 women) and Częstochowa (455.9/100,000 women), while the lowest in Świętochłowice (288.0/100,000 women), Jastrzębie Zdrój (291.4/100,000 women) and Zabrze (291.6/100,000 women). In 2017, the highest rates of

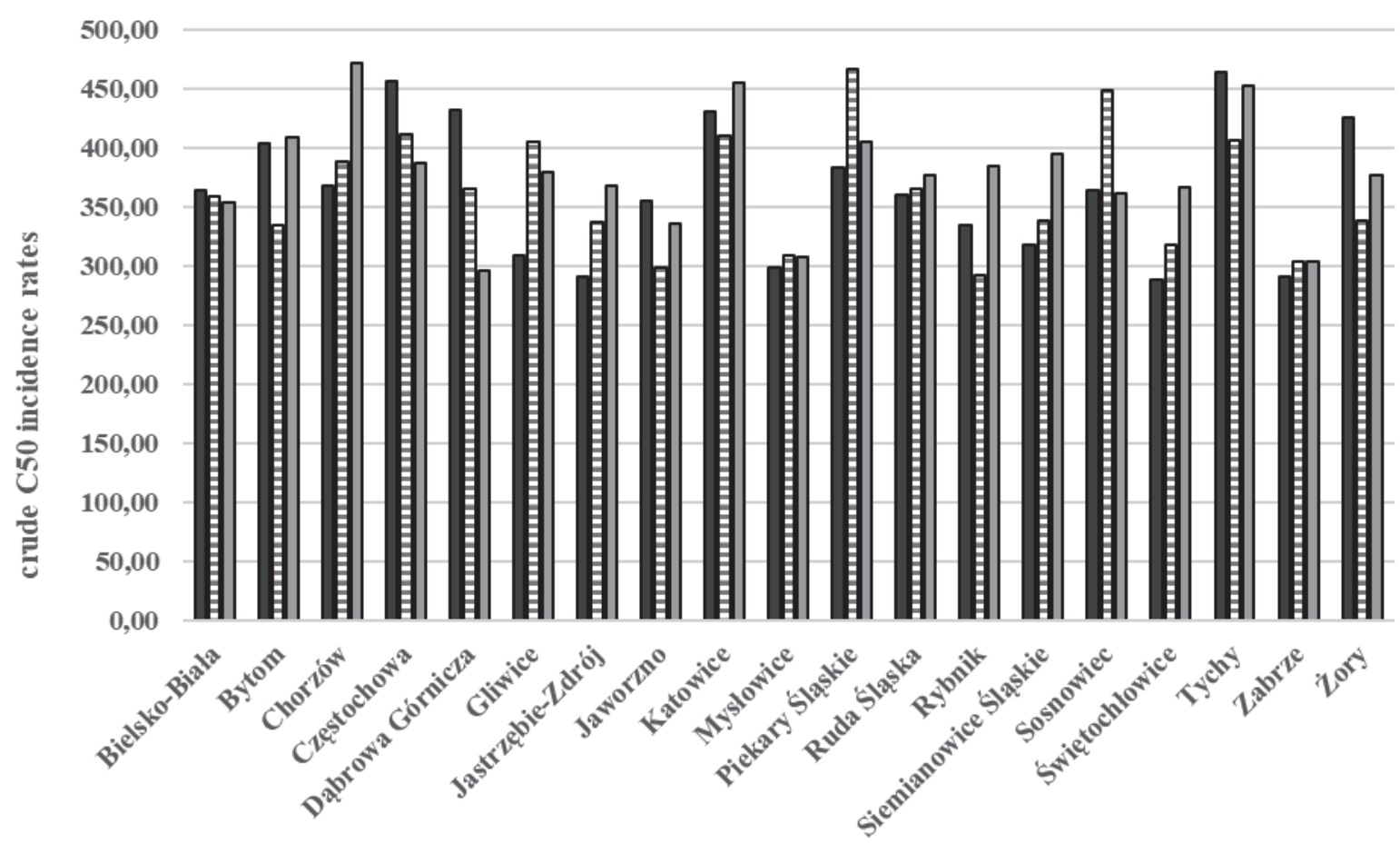

city with county rights

Fig. 1. Crude C50 incidence rates in the population of women in the peri- and postmenopausal age (45+). in the years 2016-2018. in cities with county rights in the Silesia Province - comparison of trends based on NHF data. 
breast cancer incidence were recorded in Piekary Śląskie (466.0/100,000 women) and Sosnowiec (449.0/100,000 women), and the lowest in Rybnik (292.6/100,000 women) and Jaworzno (298.7/100,000 women). In 2018, the highest values of the incidence rate were recorded in Chorzów (471.4/100,000 women), Katowice $(455.3 / 100,000$ women) and Tychy $(452.7 / 100,000)$, and the lowest in Dąbrowa Górnicza (296.5/100,000 women) and in Zabrze (304.2/100,000 women) (Fig. 1). The differences between the cities with the highest and the lowest C50 incidence rates in the female population were: in 2016-176 cases per 100,000 women - 61\%, in $2017-173$ cases per 100,000 women $-59 \%$, in $2018-175$ cases per 100,000 women $-59 \%$.

In 2016-2018, the largest upward trend in the incidence of breast cancer among women, in the periand postmenopausal period, was observed in Chorzów (28\%), Świętochłowice (27\%), Jastrzębie-Zdrój (26\%) and Siemianowice Śląskie (24\%), while a clear decrease took place in Dabrowa Górnicza (31\%), Częstochowa (15\%) and Żory (11\%). The cities of Upper Silesia with the lowest and stable C50 incidence rates in the above years (2016 and 2018 respectively) were Zabrze (291.6-304.2/100,000 women) and Mysłowice
(298.8-307.1/100 000 women), while the highest incidence is in Tychy (464.0-425.7/100,000 women) and Katowice (430.1-455.3/100 000 women) (Table 1).

When analyzing the rates of breast cancer incidence in women according to the data obtained from the National Cancer Registry, in individual cities of the Silesia Province, in years 2015-2017, the differentiation is as noticeable as in the previous analysis based on NHF data. The highest incidence rate of breast cancer in 2015 was recorded in Gliwice (260.3/100,000 women) and Częstochowa (259.3/100,000 women), while the lowest in Żory (89.4/100,000 women). In 2016, the highest value of the incidence rate was recorded in Częstochowa (232.7/100,000 women), Ruda Śląska (227.2/100,000 women) and Gliwice (223.6/100,000 women), while the lowest was in Dąbrowa Górnicza (97.1/100,000 women) and again in Żory (82.6/100,000 women). In 2017, the highest C50 incidence rate was recorded in Piekary Śląskie (250.4/100,000 women) and Gliwice (221.1/100,000 women), while the lowest was again in Żory (82.4/100,000 women) (Fig. 2). The differences between the cities with the highest and the lowest C50 incidence rates for women were,

Table 1. Crude C50 incidence rates in the population of women in the peri- and postmenopausal age (45+), in the years $2016-2018$ (rate per 100,000 women), in cities with county rights in the Silesia Province (based on NHF data).

\begin{tabular}{|c|c|c|c|c|c|}
\hline \multirow{2}{*}{ No. } & \multirow{2}{*}{ City } & \multicolumn{3}{|c|}{ Year } & \multirow{2}{*}{ Difference between 2016 and 2018 [\%] } \\
\hline & & 2016 & 2017 & 2018 & \\
\hline 1 & Bielsko-Biała & 364.29 & 359.41 & 353.27 & -3 \\
\hline 2 & Bytom & 403.23 & 334.27 & 409.35 & 2 \\
\hline 3 & Chorzów & 368.28 & 388.52 & 471.39 & 28 \\
\hline 4 & Częstochowa & 455.90 & 411.72 & 387.73 & -15 \\
\hline 5 & Dąbrowa Górnicza & 432.33 & 365.55 & 296.46 & -31 \\
\hline 6 & Gliwice & 309.57 & 405.66 & 379.65 & 23 \\
\hline 7 & Jastrzębie-Zdrój & 291.44 & 337.11 & 368.29 & 26 \\
\hline 8 & Jaworzno & 354.46 & 298.70 & 336.21 & -5 \\
\hline 9 & Katowice & 430.15 & 410.57 & 455.30 & 6 \\
\hline 10 & Mysłowice & 298.85 & 308.34 & 307.14 & 3 \\
\hline 11 & Piekary Śląskie & 382.82 & 465.96 & 404.41 & 6 \\
\hline 12 & Ruda Śląska & 359.91 & 365.09 & 377.48 & 5 \\
\hline 13 & Rybnik & 334.20 & 292.57 & 383.98 & 15 \\
\hline 14 & Siemianowice Śląskie & 317.33 & 338.77 & 394.46 & 24 \\
\hline 15 & Sosnowiec & 363.91 & 449.01 & 361.85 & -1 \\
\hline 16 & Świętochłowice & 288.00 & 318.32 & 365.96 & 27 \\
\hline 17 & Tychy & 463.95 & 405.90 & 452.70 & -2 \\
\hline 18 & Zabrze & 291.56 & 303.34 & 304.24 & 4 \\
\hline 19 & Żory & 425.47 & 338.66 & 377.36 & -11 \\
\hline
\end{tabular}

Source: own study based on NHF and CSO data 


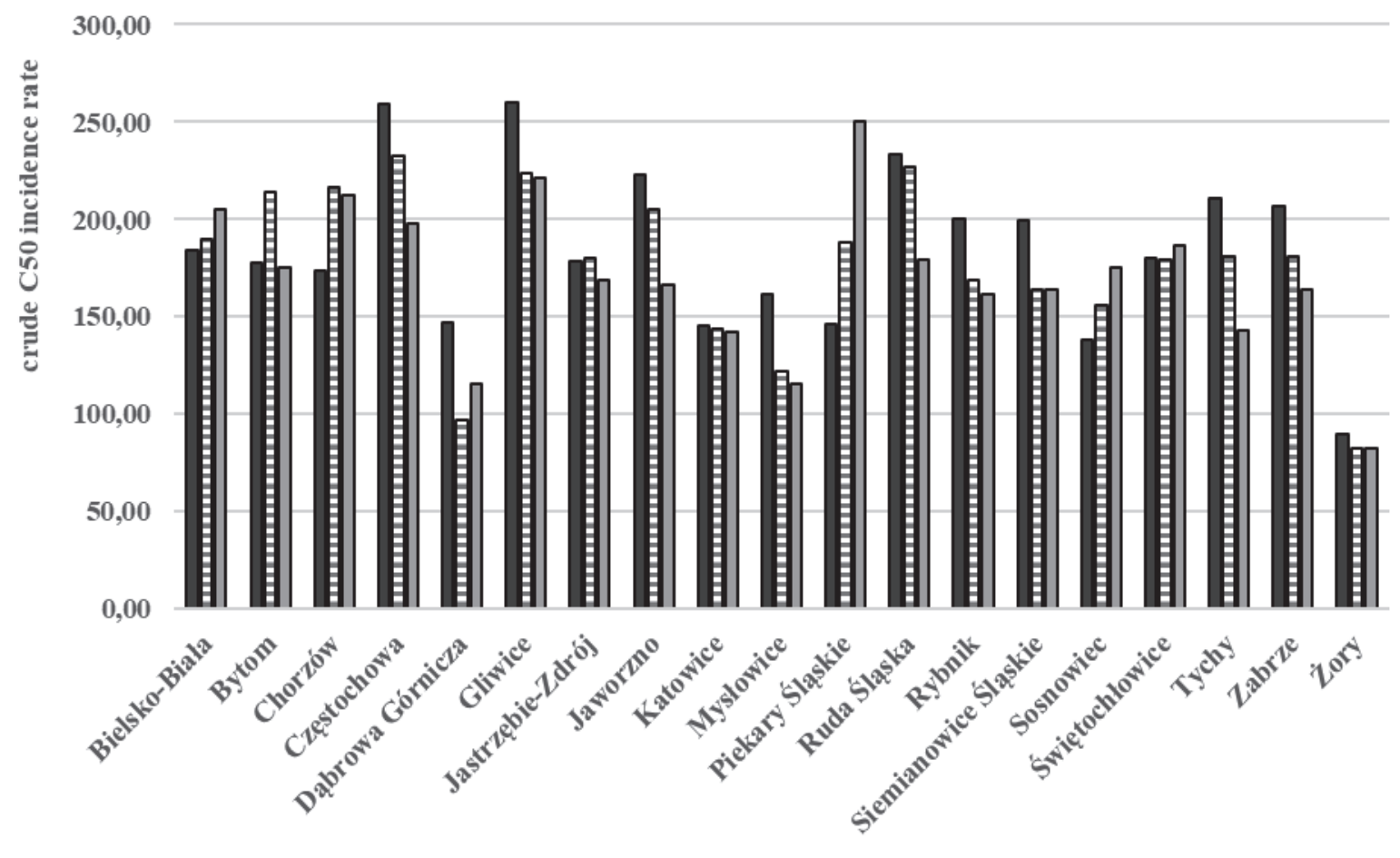

city with county rights

Fig. 2. Crude C50 incidence rates in the population of women in the peri- and postmenopausal age (45+). in the years 2015-2017 in cities with county rights in the Silesia Province - comparison of trends based on NCR data.

respectively: in 2015-171 cases per 100,000 women $191 \%$, in $2016-150$ cases per 100,000 women $-182 \%$, in $2017-168$ cases per 100,000 women $-200 \%$.

The calculations according to the NCR data in 2015-2017 show that the highest upward trend in breast cancer incidence occurs in Piekary Śląskie (71\%), Sosnowiec (27\%) and Bielsko-Biała (12\%), in the vast majority of localities there is decreases in incidence rates - in Tychy (32\%), Mysłowice (28\%), Jaworzno (25\%), Częstochowa (24\%), Ruda Śląska (23\%), Zabrze (21\%), Rybnik (19\%) and Siemianowice Śląskie (18\%) and Gliwice (15\%). The lowest and stable incidence of C50 (in 2015 and 2017 respectively) is recorded in Żory (89.4-82.6/100,000 women), while the cities with the highest rates in Upper Silesia are: in $2015-$ Gliwice (260.3/100,000 women), in 2016 - Częstochowa (232.7/100,000 women) and in 2017 - Piekary Śląskie (250.37/100,000 women) (Table 2).

In order to compare the reporting of new cases of breast cancer in two databases available in Poland, i.e. the NHF and the NCR, the curves of new C50 cases recorded in both databases in the population of peri- and postmenopausal women, living in 19 cities with county rights in the Silesia Province, have been plotted. The collected data made it possible to compare the number of new C50 cases recorded in 2016 and 2017 in each of the 19 analyzed cities (Figs 3 and 4).
The data of the Silesia Province Department of the National Health Fund (SPD NHF) show that in 2016 in the 19 analyzed cities of the Silesia Province, the number of new cases in which the main reason for the provision of health services was a code C50 was 2,480 (Fig. 3). The number of new breast cancer cases in women in peri- and postmenopausal period reported to the National Cancer Registry from 19 cities in Silesia Province for 2016 was two times lower - 1,210. In 2017, the number of new cases of C50 in women over 45 years of age, recorded in the SPD NHF, amounted to 2,467 , and similarly to 2016 , it was twice as high as the number reported by the NCR $(1,152)$ in a specific population of women (Fig. 4). In each of the analyzed cities, the data obtained from the SPD NHF database in the number of cases exceed the data reported to the NCR. In individual cities, the discrepancies between the data range from 14 new cases in Świętochłowice to 232 in Katowice - in 2016, and in 2017 from 17 cases again in Świętochłowice to 227 in Częstochowa. Despite such a large difference in the number of registered cases between the National Health Fund and the National Cancer Registry, the territorial incidence trend is exactly the same for both registers, both for 2016 and 2017.

Analyzing the average annual concentrations of air pollutants, based on the measurements of benzo(a) pyrene $(\mathrm{BaP})$, cadmium $(\mathrm{Cd})$ and particulate matter 
Table 2. Crude C50 incidence rates in the population of women in the peri- and postmenopausal age (45+), in the years 2015 -2017 (rate per 100,000 women), in cities with county rights in the Silesia Province (based on NCR data).

\begin{tabular}{|c|c|c|c|c|c|}
\hline \multirow{2}{*}{ No. } & \multirow{2}{*}{ City } & \multicolumn{3}{|c|}{ Year } & \multirow{2}{*}{$\begin{array}{l}\text { Difference between } 2015 \text { and } \\
2017[\%]\end{array}$} \\
\hline & & 2016 & 2017 & 2018 & \\
\hline 1 & Bielsko-Biała & 183.80 & 189.97 & 205.38 & 12 \\
\hline 2 & Bytom & 178.05 & 214.15 & 175.09 & -2 \\
\hline 3 & Chorzów & 174.01 & 216.64 & 212.25 & 22 \\
\hline 4 & Częstochowa & 259.33 & 232.70 & 197.94 & -24 \\
\hline 5 & Dąbrowa Górnicza & 147.45 & 97.12 & 115.60 & -22 \\
\hline 6 & Gliwice & 260.29 & 223.58 & 221.07 & -15 \\
\hline 7 & Jastrzębie-Zdrój & 178.58 & 180.41 & 168.56 & -6 \\
\hline 8 & Jaworzno & 222.79 & 204.99 & 166.42 & -25 \\
\hline 9 & Katowice & 145.66 & 144.21 & 142.21 & -2 \\
\hline 10 & Mysłowice & 161.18 & 121.76 & 115.63 & -28 \\
\hline 11 & Piekary Śląskie & 146.05 & 187.93 & 250.37 & 71 \\
\hline 12 & Ruda Śląska & 233.05 & 227.16 & 179.60 & -23 \\
\hline 13 & Rybnik & 200.52 & 168.63 & 161.52 & -19 \\
\hline 14 & Siemianowice Śląskie & 199.12 & 164.33 & 163.74 & -18 \\
\hline 15 & Sosnowiec & 138.22 & 155.71 & 175.40 & 27 \\
\hline 16 & Świętochłowice & 179.87 & 179.03 & 186.34 & 4 \\
\hline 17 & Tychy & 210.65 & 181.13 & 142.70 & -32 \\
\hline 18 & Zabrze & 206.98 & 180.82 & 164.03 & -21 \\
\hline 19 & Żory & 89.37 & 82.62 & 82.45 & -8 \\
\hline
\end{tabular}

Source: own study based on NCR and CSO data

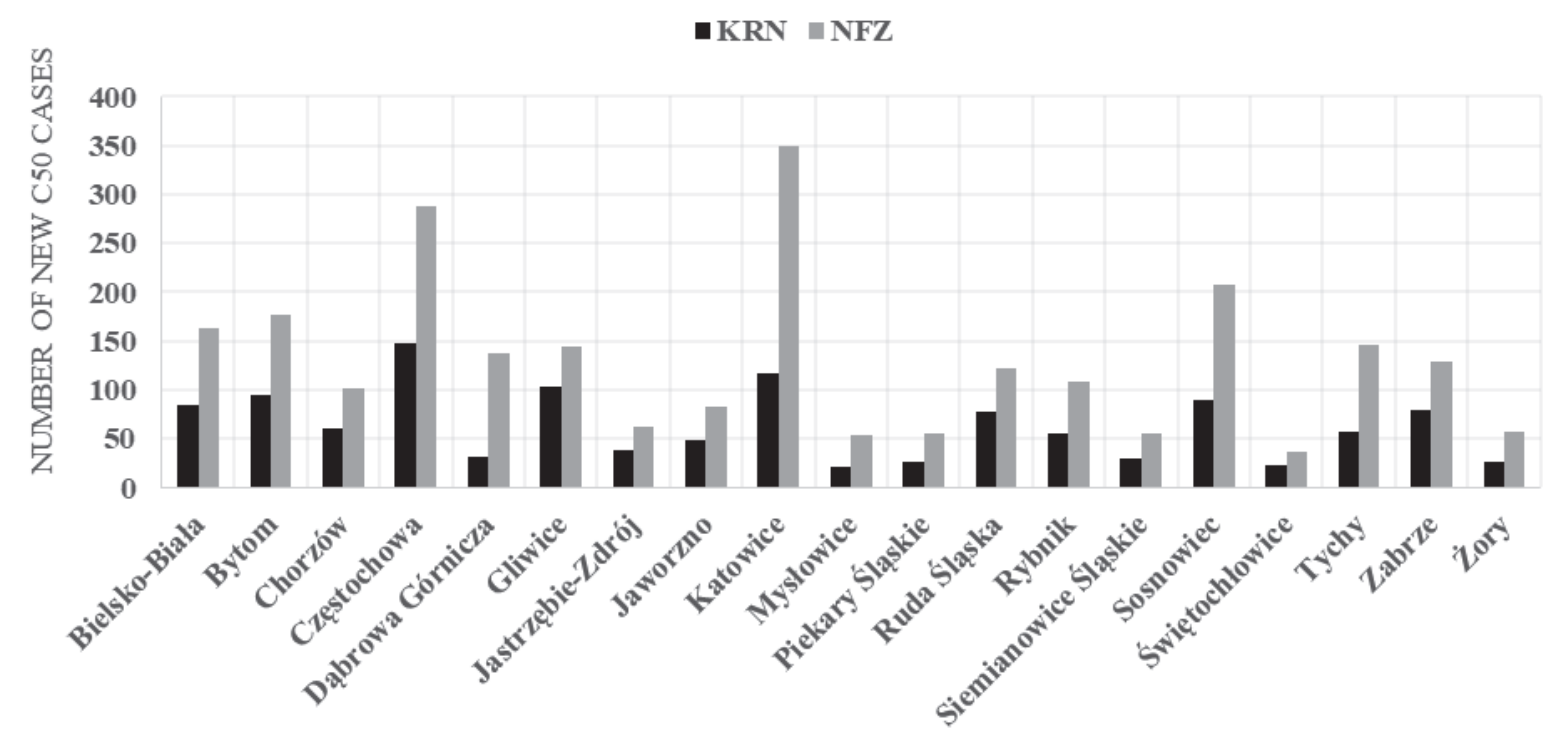

\section{CITY WITH COUNTY RIGHTS}

Fig. 3. The number of new C50 cases in the female population at the peri- and postmenopausal age, in cities with county rights in the Silesia Province, recorded in 2016 by the NHF and the NCR. 


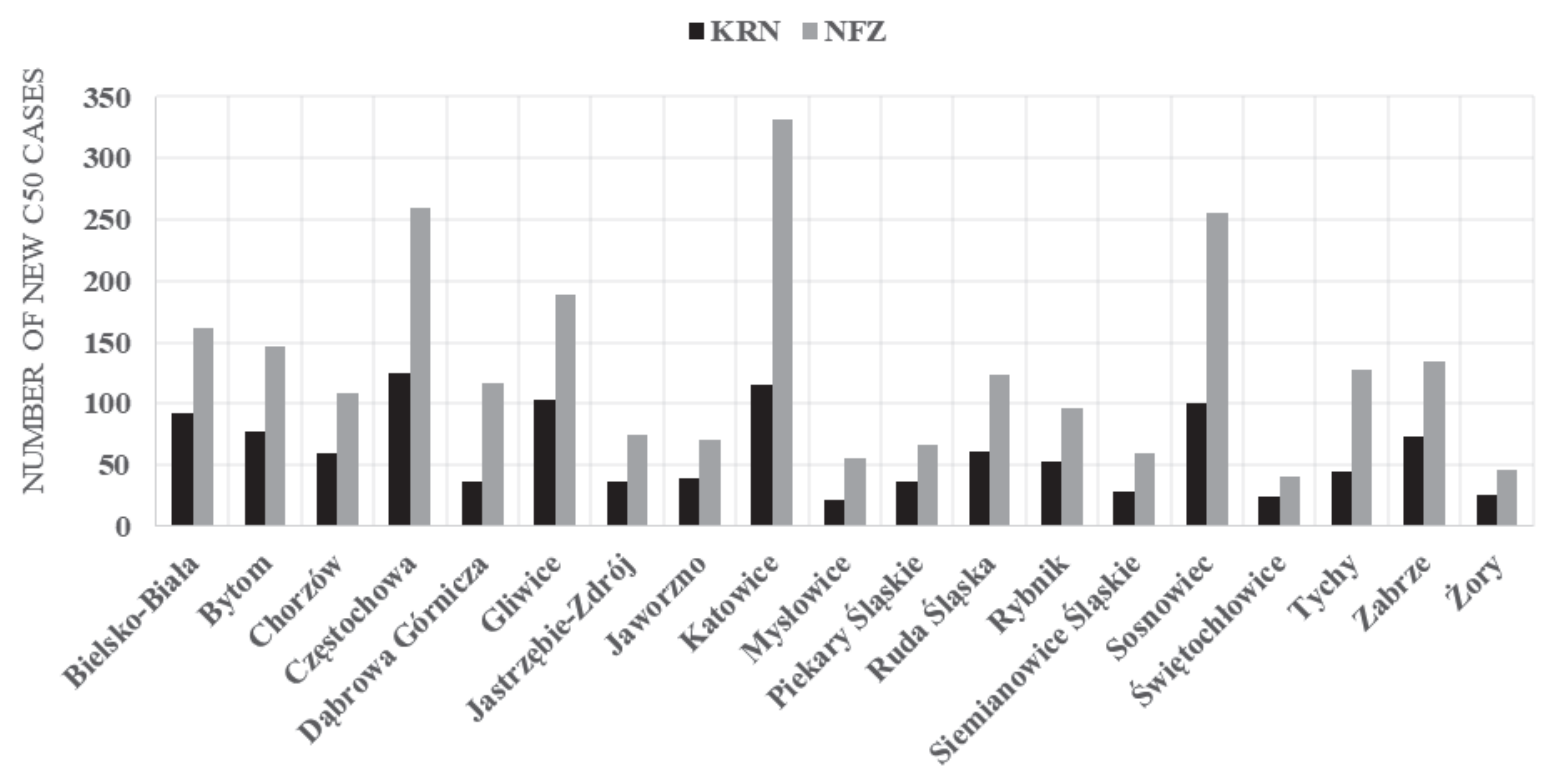

CITY WITH COUNTY RIGHTS

Fig. 4. The number of new $\mathrm{C} 50$ cases in the female population at the peri- and postmenopausal age, in cities with county rights in the Silesia Province, recorded in 2017 by the NHF and the NCR.

$\mathrm{PM}_{10}$ fraction in 19 cities of the Silesia Province, in the years 1989-2008, significant territorial differentiation of individual pollutants is visible (Table 3).

Over the 20 analyzed years, the BaP level reached the highest average annual value in Świętochłowice $69.6 \mathrm{ng} / \mathrm{m}^{3}$, in Siemianowice Śląskie - $46.68 \mathrm{ng} / \mathrm{m}^{3}$ and Chorzów - $41.31 \mathrm{ng} / \mathrm{m}^{3}$, while the lowest in BielskoBiała - $13.51 \mathrm{ng} / \mathrm{m}^{3}$ and Częstochowa - $8.83 \mathrm{ng} / \mathrm{m}^{3}$. The difference between the highest and the lowest concentration of benzo(a)pyrene in the air in Silesia Province is almost eightfold $-790 \%$ (Table 3).

The average annual concentration of cadmium in the air in the indicated 20-year period was as follows: the highest level was recorded in Piekary Śląskie - $10.48 \mathrm{ng} / \mathrm{m}^{3}$ and in Bytom - $8.73 \mathrm{ng} / \mathrm{m}^{3}$, while the lowest in Jastrzębie-Zdrój - $2.70 \mathrm{ng} / \mathrm{m}^{3}$ and in Częstochowa - $2.29 \mathrm{ng} / \mathrm{m}^{3}$. There is a fourfold difference between the highest and the lowest concentration of cadmium in the air of Upper Silesia cities $-457 \%$ (Table 3 ).

The average annual concentration of $\mathrm{PM}_{10}$ fraction in the air, in the period 1989-2008, in 19 Silesian cities is also non-uniform. The city with the highest $\mathrm{PM}_{10}$ concentration index was Świętochłowice - $139.11 \mu \mathrm{g} / \mathrm{m}^{3}$, next with almost the same level were Siemianowice Śląskie - $98.68 \mu \mathrm{g} / \mathrm{m}^{3}$ and Chorzów $-98.26 \mu \mathrm{g} / \mathrm{m}^{3}$, while the lowest values were recorded in Częstochowa - $45.50 \mu \mathrm{g} / \mathrm{m}^{3}$ and Bielsko-Biała - $43.89 \mu \mathrm{g} / \mathrm{m}^{3}$. The difference in the recorded concentrations between the highest and the lowest $\mathrm{PM}_{10}$ value in Silesian cities was more than threefold $-317 \%$ (Table 3).

When analyzing the average concentration of dioxins and furans (PCDD/Fs) in selected cities of the Silesia Province, determined in 2014, significant territorial differentiation was observed. The highest value of dioxins was recorded in the territory of Zabrze (161.3 fg I-TEQ $/ \mathrm{m}^{3}$ ) and Gliwice (142.9 $\left.\mathrm{fg} \mathrm{I}-\mathrm{TEQ} / \mathrm{m}^{3}\right)$, the lowest equal values were recorded in Bielsko-Biała and Rybnik (78.3 fg I-TEQ $/ \mathrm{m}^{3}$ ). The difference between the extreme values of dioxins and furans, observed in individual cities, was more than twofold. In the values of polychlorinated biphenyls (PCBs), recorded in the same period in the air of analyzed localities, an equally large range was observed. The highest average PCBs concentration was determined in Bytom (12 fg $\mathrm{I}-\mathrm{TEQ} / \mathrm{m}^{3}$ ), then in Chorzów and Gliwice (10.8 $\mathrm{fg} \mathrm{I}-\mathrm{TEQ} / \mathrm{m}^{3}$ ), while the lowest average concentration was determined in Rybnik (4.3 fg $\left.\mathrm{I}-\mathrm{TEQ} / \mathrm{m}^{3}\right)$. The territorial differentiation in the concentration of polychlorinated biphenyls in the studied area of Silesia Province reached 280\% (Table 4).

The conducted analysis of the linear correlation did not show a statistically significant relationship between the studied variables (Table 5). Also, statistical analysis with the use of multiple regression did not show a statistically significant relationship between the studied variables.

Breast cancer is currently the greatest oncological threat to the population of women, both globally and in Poland, especially in the age group over 45. Unfortunately, there is no indication that this state of affairs has changed, even a systematic increase in the incidence of this type of cancer is forecast as a consequence of aging populations and the constantly growing exposure to modifiable risk factors contributing to its development [11]. An undoubted fact is the large territorial differentiation of registered oncological 
Table 3. Average concentrations of $\mathrm{BaP}, \mathrm{Cd}$ and $\mathrm{PM}_{10}$ in the air in cities with county rights in the Silesia Province in the years 1989-2008.

\begin{tabular}{|c|c|c|c|}
\hline \multirow{2}{*}{ City } & $\mathrm{BaP}$ & $\mathrm{Cd}$ & $\mathrm{PM}_{10}$ \\
\hline & {$\left[\mathrm{ng} / \mathrm{m}^{3}\right]$} & {$\left[\mathrm{ng} / \mathrm{m}^{3}\right]$} & {$\left[\mu \mathrm{g} / \mathrm{m}^{3}\right]$} \\
\hline Bielsko-Biała & 13.51 & 2.86 & 43.89 \\
\hline Bytom & 36.59 & 8.73 & 95.09 \\
\hline Chorzów & 41.31 & 7.06 & 98.26 \\
\hline Częstochowa & 8.83 & 2.29 & 45.50 \\
\hline Dąbrowa Górnicza & 26.63 & 3.99 & 70.95 \\
\hline Gliwice & 28.74 & 3.05 & 76.20 \\
\hline Jastrzębie-Zdrój & 25.61 & 2.70 & 74.65 \\
\hline Jaworzno & 31.43 & 3.54 & 80.65 \\
\hline Katowice & 29.55 & 5.20 & 82.43 \\
\hline Mysłowice & 32.30 & 4.53 & 82.95 \\
\hline Piekary Śląskie & 36.06 & 10.49 & 91.65 \\
\hline Ruda Śląska & 32.12 & 3.95 & 86.22 \\
\hline Rybnik & 32.22 & 2.93 & 83.85 \\
\hline Siemianowice Śląskie & 46.68 & 6.54 & 98.68 \\
\hline Sosnowiec & 31.91 & 5.94 & 86.03 \\
\hline Świętochłowice & 69.60 & 7.17 & 139.11 \\
\hline Tychy & 24.75 & 2.82 & 70.85 \\
\hline Zabrze & 34.28 & 4.27 & 97.45 \\
\hline Żory & 29.41 & 2.84 & 80.70 \\
\hline
\end{tabular}

Source: own study based on data obtained from the Reports of the Provincial Sanitary and Epidemiological Station in Katowice, Poland

cases, both at the global and European level, as well as within individual countries. The Silesia Province, characterized by a high degree of industrialization, a high percentage of inhabitants in cities and, above all, the highest level of environmental pollution in Poland, stands out from other provinces [12].

Mielecka-Kubień [12] in 2017, in her analysis of the health condition of inhabitants in terms of the degree of environmental pollution in Polish provinces in 2013, quite clearly proved the risk of cancerous diseases among the female population of the Silesia Province. The territorial differentiation of the incidence of breast cancer in women is also noticeable within the Silesia Province itself, between cities with county rights. The analysis of the C50 incidence rates for women in 2016-2018, obtained from the Silesia Province Department of the National Health Fund, shows an average $60 \%$ difference in the incidence between cities. In 2016, the city with the highest C50 incidence rate was Tychy (463.9/100,000 women), and the lowest Świętochłowice (288.0/100,000 women); the difference
Table 4. Average concentrations of PCDD/Fs and PCBs in the air in cities with county rights in the Silesia Province (period of 2 months from December 2014).

\begin{tabular}{|c|c|c|}
\hline City & $\begin{array}{c}\Sigma \mathrm{PCDD} / \mathrm{F} \\
{\left[\mathrm{fg} \text { I-TEQ } / \mathrm{m}^{3}\right]}\end{array}$ & $\begin{array}{c}\Sigma \mathrm{dl}-\mathrm{PCB} \\
{\left[\mathrm{fg} \mathrm{I}-\mathrm{TEQ} / \mathrm{m}^{3}\right]}\end{array}$ \\
\hline Bielsko-Biała & 78.3 & 5.2 \\
\hline Bytom & 119.8 & 12 \\
\hline Chorzów & 119.8 & 10.8 \\
\hline Częstochowa & 101.4 & 7.1 \\
\hline Dąbrowa Górnicza & 92.2 & 6.1 \\
\hline Gliwice & 142.9 & 10.8 \\
\hline Katowice & 115.2 & 5.4 \\
\hline Rybnik & 78.3 & 4.3 \\
\hline Sosnowiec & 82.9 & 5.1 \\
\hline Tychy & 124.4 & 5.3 \\
\hline Zabrze & 161.3 & 5.4 \\
\hline Żory & 101.4 & 5.2 \\
\hline
\end{tabular}

Source: own study [21].

was 61\%. In 2017, the highest C50 incidence was recorded in Piekary Śląskie (466.0/100,000 women), while in Rybnik (292.6/100,000 women) was 59\% lower. In 2018, the highest incidence was recorded in Chorzów (471.4/100,000 women), while in Dąbrowa Górnicza the C50 incidence rate was 59\% lower (296.5/100,000 women). The C50 incidence rates for women, obtained from the National Cancer Registry in 2015-2017, show significantly lower values in individual cities compared to the National Health Fund, with higher territorial differentiation, reaching even 200\%. The lowest, slightly different rates of breast cancer incidence in each subsequent year studied were recorded in Żory, where they were successively: in 2015-89.4/100,000 women, in 2016-82.6/100,000 women, in 2017-82.4/100,000 women. The highest incidence in 2015 was recorded in Gliwice (260.3/100,000 women) - the differentiation was $191 \%$, in 2016 in Częstochowa (232.7/100,000 women), with the incidence differentiation by $182 \%$ and in 2017 in Piekary Śląskie (250.4/100,000 women), leading to a $200 \%$ difference.

Zemła et al. [13] described a large territorial differentiation in the incidence of malignant neoplasms in the female population of the Silesia Province in a study of 2012. In the years 1999-2009, the authors of the study compared the average rates of female breast cancer incidence calculated for the extreme four-year periods, i.e. 1999-2002 and 2006-2009, obtaining the highest value of the ratio in the first period, amounting to $246.0 / 100,000$, and the lowest - 150.8/100,000 women. In the years 2006-2009 the highest value of the ratio was estimated at the level of $235.4 / 100,000$ women and the lowest $-149.2 / 100,000$ women. In their 
Table 5. Linear correlation results.

\begin{tabular}{|c|c|c|}
\hline \multicolumn{2}{|c|}{ Studied variables } & \multirow{2}{*}{ p-value } \\
\hline $\mathrm{x}$ & $\mathrm{y}$ & \\
\hline Mean breast cancer incidence rate (NCR) & $\mathrm{BaP}$ concentration in the air & 0.74 \\
\hline Mean breast cancer incidence rate (NHF) & $\mathrm{BaP}$ concentration in the air & 0.94 \\
\hline Mean breast cancer incidence rate (NCR) & $\mathrm{Cd}$ concentration in the air & 0.87 \\
\hline Mean breast cancer incidence rate (NHF) & Cd concentration in the air & 0.53 \\
\hline Mean breast cancer incidence rate (NCR) & $\mathrm{PM}_{10}$ suspended dust concentration in the air & 0.93 \\
\hline Mean breast cancer incidence rate (NHF) & $\mathrm{PM}_{10}$ suspended dust concentration in the air & 0.78 \\
\hline Mean breast cancer incidence rate (NCR) & $\mathrm{PCDD} / \mathrm{Fs}$ concentration in the air & 0.71 \\
\hline Mean breast cancer incidence rate (NHF) & $\mathrm{PCDD} / \mathrm{Fs}$ concentration in the air & 0.92 \\
\hline Mean breast cancer incidence rate (NCR) & PCBs concentration in the air & 0.27 \\
\hline Mean breast cancer incidence rate (NHF) & PCBs concentration in the air & 0.97 \\
\hline
\end{tabular}

Source: own study.

work, the authors indicated the existence of endemic with both the highest and the lowest rates of malignant neoplasm incidence in the female population in the Silesia Province. The endemic cities with the highest risk of malignant neoplasms among women were then: Chorzów, Dąbrowa Górnicza, Gliwice, Jastrzębie-Zdrój, Jaworzno and Katowice, which are also mentioned in the own study.

The clearly differentiated incidence of breast cancer among women, in terms of individual provinces in Poland, was presented by Szkiela et al. [14]. In this study, the analysis was based on the estimation of the percentage of breast cancer incidence in the overall cancer incidence rate in the population of women in Poland in 2001-2011. The study showed the lowest percentage of breast cancer cases in the following years, in the provinces: Lubelskie in 2001 (18.24\%), Podkarpackie in 2002, 2005, 2007 (17.55\%, 16.61\% and $17.54 \%$, respectively) and Świętokrzyskie in 2010 and 2011 (17.9\% and 18.4\%, respectively). The highest incidence levels in the analyzed period were obtained by the authors in the following provinces: Lubuskie in 2001 and 2002 (26.25\% and $25.36 \%$, respectively), in Zachodniopomorskie in 2005 (24.03\%), in Mazowieckie in 2007 (24.55\%) and in 2010 and 2011 again in the Zachodniopomorskie ( $27.08 \%$ and $27.89 \%$, respectively). The results of this study illustrate quite vividly the spatial differentiation of breast cancer incidence in Poland.

The graph of the curve of new cases of breast cancer in peri-and postmenopausal women, according to the data of the Silesia Province Department of the National Health Fund, does not coincide with the incidence curve registered by the National Cancer Registry, but is a reflection of it, both in the 2016 and 2017 analyzed years. According to the data of the SPD NHF, in 2016 and 2017, in the analyzed cities of the Silesia Province, the number of new C50 cases for which the medical health service was provided amounted to 2,480 and 2,467 , respectively. Data on the number of new cases of breast cancer in women over 45 years of age, reported to the National Cancer Registry for 2016 and 2017, were two times lower (1,210 and 1,152, respectively). Similar results were reported by Misiak et al. [15] in a study from 2017, compiling also the numerical data of new cases of breast cancer in the population of women living in 19 cities of the Silesia Province, obtained from the NHF and NCR in 2012. From the data registered in the NCR the authors received 1,290 new cases of breast cancer and more than twice as many services provided by the National Health Fund (NHF) due to developing C50, amounting to 2,850 cases. The authors of the study obtained a similar curve of new C50 cases from the calculations according to the SPD NHF data, duplicating the territorial incidence trend in 2012, resulting from the NCR data, to that presented in the own study. The cities mentioned in the study, characterized by the greatest diversity in the number of registered cases of breast cancer (according to the NHF and the NCR), were also included in own study Częstochowa and Katowice.

The probable cause of such large discrepancies in research can be seen in slightly different goals and tasks for which both registers (NHF and NCR) were created and in the lack of data flow between them. This result raises concerns about the possible underestimation or lack of full reporting to the NCR of all entities obliged to this task. The model register would be the Cancer Registry based on a single database connected to all hospital systems, histopathological laboratories, general population registration system, in the form of a register currently used in Finland [16].

In the levels of concentrations of environmental pollutants, which are most often attributed to neoplasms 
within the mammary gland, there is also a large territorial differentiation in the Silesia Province. Over the 20 years under study, the concentration of benzo(a) pyrene fluctuated between the lowest value recorded in Częstochowa $-8.83 \mathrm{ng} / \mathrm{m}^{3}$, and almost eight times higher in Świętochłowice - $69.6 \mathrm{ng} / \mathrm{m}^{3}$. The average concentration of cadmium in atmospheric air was similar in the analyzed period, where the lowest value was also recorded in Częstochowa - $2.29 \mathrm{ng} / \mathrm{m}^{3}$, with a simultaneous almost five times higher level of this pollution in Piekary Śląskie - $10.48 \mathrm{ng} / \mathrm{m}^{3}$. Świętochłowice turned out to be the city with the highest concentration of $\mathrm{PM}_{10}$ suspended dust $\left(139.11 \mu \mathrm{g} / \mathrm{m}^{3}\right)$, while in Bielsko-Biała the concentration was three times lower $\left(43.89 \mu \mathrm{g} / \mathrm{m}^{3}\right)$. The concentrations of the above pollutants, despite a very large spatial differentiation, were and still are several times higher than those recorded in other provinces. The lowest B(a) $\mathrm{P}$ values in the atmospheric air in Silesia Province, occurring in Częstochowa, were almost three times higher than the highest concentration of this pollutant, presented in the study by Gębicki [17] from 2015, covering the area of Olsztyn and Elbląg (cities with county rights in Warmińsko-Mazurskie Province). The author of the study, conducted in 2010-2013, obtained the average annual concentration of $\mathrm{B}(\mathrm{a}) \mathrm{P}$ in suspended dust ranging between $1.34 \mathrm{ng} / \mathrm{m}^{3}$ and $3.30 \mathrm{ng} / \mathrm{m}^{3}$. Trojanowska [18] in her 2012 study described the cadmium concentrations obtained in 2007-2009 in the atmospheric air in the largest urban agglomerations in Poland. According to her research, the highest inhalation dose of cadmium was taken by the inhabitants of the Kraków agglomeration $\left(1.55 \mathrm{ng} / \mathrm{m}^{3}\right)$, followed by the inhabitants of the Upper Silesia agglomeration $\left(1.52 \mathrm{ng} / \mathrm{m}^{3}\right)$, while the lowest doses were taken by the inhabitants of the Poznań agglomeration $\left(0.31 \mathrm{ng} / \mathrm{m}^{3}\right)$. The values of the average cadmium concentration in the atmospheric air presented by the Author were many times lower than those presented in this study, which may be related to a much shorter period of analysis. In the own study, the concentrations of $\mathrm{Cd}$ in the years from 1989 to 2008 were taken into account, where at the beginning of this period, when the industry in Upper Silesia was booming, the levels of air pollutants were many times higher than in the present and previous decades. Pasela et al. [19], analyzing the results of measurements of air pollution with particulate matter $\mathrm{PM}_{10}$ in Bydgoszcz in 2013-2015, obtained the average annual concentration of this fraction ranging from $40-42 \mu \mathrm{g} / \mathrm{m}^{3}$, emphasizing the achieved limit level established for the protection of human health. Bydgoszcz is the largest city in the Kujawsko-Pomorskie Province, with a population of over 350,000, where the exposure of this population to air pollution by $\mathrm{PM}_{10}$ particulate matter is lower than the lowest concentration obtained in own study, recorded in Bielsko-Biała. In the period analyzed in this study, the concentrations of PCDDs, PCDFs and PCBs in the air were the least threatening for the inhabitants of Bielsko-Biała and Rybnik, while the inhabitants of Zabrze, Bytom, Chorzów and Gliwice were the most exposed.

The analyzes of the concentrations of dust pollutants present in the atmospheric air in 19 cities of the Silesia Province indicate such a large spatial differentiation that it is not possible to clearly indicate the locations with all the highest or all the lowest levels of the analyzed pollutants. After analyzing the correlations between territorially differentiated rates of breast cancer incidences and the level of pollutants concentrations in this area, no statistically significant correlations were obtained. The obtained results of statistical analysis emphasize, on the one hand, the importance of too many chemical compounds with carcinogenic potential in the area of the breast gland, and on the other hand, their too large spatial dispersion. Moreover, significant factors disturbing the statistical analysis are probably a large number of risk factors, apart from environmental pollution, influencing the formation of breast cancer in the population of periand postmenopausal women. It is undoubted, however, that the recorded such high (the highest in Poland) concentrations of air pollutants are involved in inducing the neoplastic process in the breast. In 2018, Rodgers et al. [20] presented a series of studies providing scientific evidence of the impact of environmental pollutants on carcinogenesis in the mammary gland. In an extensive collection of studies, significant relationships between environmental pollutants and reported cases of disease among women from polluted areas were indicated. The authors of the research indicate the strongest threats posed by dioxin compounds, polychlorinated biphenyls, polycyclic aromatic hydrocarbons and organic solvents. The cited publication is to a large extent an attempt to determine the degree of risk of developing C50 in the face of the increasing number of environmental threats. The compounds for which a high proliferative potential within the mammary gland is also found are heavy metals, pesticides (organophosphorus and organochlorine), phthalates, bisphenol A, parabens and alkyl phenols. The relationships presented by the Authors are largely based on many years of case-control studies, in vitro experiments with breast cancer cell lines, and in vivo experiments in mice and rats.

The still growing global incidence of breast cancer among women is a significant public health problem. The barrier to solving this problem is the lack of an appropriate method of assessing exposure to the disease, which is sensitive to such a wide range of factors and develops over several dozen years. The priority of actions in the field of public health should be the elimination of avoidable environmental pollutants or their significant reduction, in particular common dust air pollutants, and properly conducted prevention programs. 


\section{Conclusions}

The conducted research allowed to draw the following conclusions:

1. The significant differentiation of breast cancer incidence rates in peri- and postmenopausal women in 19 cities with county rights in the Silesia Province may indicates the existence of environmental determinants of the carcinogenic process.

2. No statistically significant relationships were found between the incidence of breast cancer in the population of women in the analyzed Silesian cities, at peri- and postmenopausal age, and the concentration of selected particulate air pollutants $\left(\mathrm{Cd}, \mathrm{BaP}, \mathrm{PM}_{10}, \mathrm{PCDD} / \mathrm{Fs}, \mathrm{PCBs}\right)$, which may be associated with numerous risk factors for the occurrence of this type of malignancy.

3. Studies have shown clear differences in the number of new cases of breast cancer reported in the population of women over 45 years of age by the National Cancer Registry and the National Health Fund, which demonstrates the limitations of the healthcare management system related to the lack of cooperation between the two systems.

4. Cooperation between the NHF and the NCR or the creation of a new, integrated database on the number of cancer cases in the Polish population would allow for the introduction of effective preventive measures aimed at modifiable risk factors, including environmental factors, and consequently contribute to reducing the number of cancer cases.

\section{Acknowledgments}

The present study was funded by the Medical University of Silesia in Katowice, Poland - Grants number: KNW-1-134/N/8/Z and KNW-1-099/N/9/Z.

\section{Conflict of Interest}

The authors declare no conflict of interest.

\section{References}

1. BRAY F., FERLAY J., SOERJOMATARAM I., SIEGEL R., TORRE L., JEMAL A. Global Cancer Statistics 2018: GLOBOCAN Estimates of Incidence and Mortality Worldwide for 36 Cancers in 185 Countries. CA Cancer J Clin, 68, 394, 2018.

2. JASSEM J., KRZAKOWSKI M. Breast cancer. Oncol Clin Pract, 14 (4), 171, 2018. DOI: 10.5603/OCP.2018.0027.

3. JASSEM J., KRZAKOWSKI M. Breast cancer. Oncol Clin Pract, 16 (5), 207, 2020. DOI: 10.5603/OCP.2018.0027.

4. DIDKOWSKA J., WOJCIECHOWSKA U., CZADERNY K. Malignant neoplasms in Poland in 2017. Maria Sklodowska-Curie National Research Institute of Oncology: Warszawa, Poland, 2019 [In Polish].
5. DIDKOWSKA J., WOJCIECHOWSKA U., OLASEK P. Malignant neoplasms in Poland in 2015. Maria Sklodowska-Curie National Research Institute of Oncology: Warszawa, Poland, 2017 [In Polish].

6. PAWLICKI M. Breast cancer - new hopes and treatment options. Publishing Center „Augustana”: Bielsko-Biała, Poland, 2011 [In Polish].

7. KRALOVA K., JAMPILEK J. Impact of Environmental Contaminants on Breast Cancer. Ecol Chem Eng S, 22 (1), 9, 2015. DOI: 10.1515/eces-2015-0001.

8. KUMARAGURUPARAN R., CHANDRA MOHAN K., NAGINI S. Xenobiotic-metabolising enzymes in patients with adenocarcinoma of the breast: Correlation with clinical stage and menopausal status. The Breast, 15 (1), 58, 2006. DOI: 10.1016/j.breast.2005.04.012.

9. GÓRALCZYK K., HERNIK A., CZAJA K., STRUCINSKI P., KORCZ W., SNOPCZYNSKI T., LUDWICKI J.K. Organohalogen compounds - old and new threats to humans. Annals of the National Institute of Hygiene, 61 (2), 109, 2010 [In Polish].

10. INTERNATIONAL AGENCY FOR RESEARCH ON CANCER. IARC: Outdoor air pollution a leading environmental cause of cancer deaths. WHO, 2013. URL: https://www.iarc.who.int/wp-content/uploads/2018/07/ pr221_E.pdf [Access: 05.02.2021]

11. GARWACKA-CZACHOR E., MACIEJCZYK A., BĘBENEK M. The sociodemographic profile of women participating in mammography screening in Lower Silesia. J Oncol, 67, 89, 2017 [In Polish].

12. MIELECKA-KUBIEŃ Z. Health condition of inhabitants and environmental pollution in the provinces system. Statistical analysis. Scientific journals of the University of Economics in Katowice, 318, 53, 2017 [In Polish].

13. ZEMŁA B., BANASIK T., KOŁOSZA Z. Endemics with the highest and lowest incidence of malignant neoplasms in general within the Silesia Province. Environmental Medicine, 15 (3), 35, 2012 [In Polish].

14. SZKIELA M., WORACH-KARDAS H., MARCINKOWSKI J. Malignant breast cancer epidemiology, risk factors, importance of primary and secondary prevention. Problems of Hygiene and Epidemiology, 95 (2), 292, 2014 [In Polish].

15. MISIAK J., ROGALA D., BOCIONEK A., BORATYNNOWICKA A., GRUND D., KRUKOWSKA J. The analysis of breast cancer and colorectal cancer incidence in Silesian province based on available data on malignancies - National Cancer Registry and National Health Fund. Ann. Acad. Med. Siles., 71, 148, 2017. DOI:10.18794/ aams $/ 64313$.

16. WOJCIECHOWSKA U., DIDKOWSKA J., KOĆMIEL A. Malignant neoplasms in Poland as a problem of public health. Demographic Studies, 1, 161, 2012 [In Polish]. DOI: $10.2478 / \mathrm{v} 10274-012-0007-6$.

17. GĘBICKI J., LUDKIEWICZ T., NAMIEŚNIK J. Determination of benzo(a)pyrene content in PM10 using regression methods. Environmental Medicine, 18 (4), 23, 2015.

18. TROJANOWSKA M., ŚWIETLIK R. Inhalative environmental exposure of inhabitants of Polish cities to heavy metals, cadmium, nickel and arsenic. Environmental Medicine, 15 (2), 33, 2012 [In Polish].

19. PASELA R., MILIK J., BUDZIŃSKA K., SZEJNIUK B. Analysis of the measurement results of air pollution concentrations with $\mathrm{PM}_{10}$ and $\mathrm{PM}_{2.5}$ dust at the Poznan Square measuring station in Bydgoszcz. Ecological 
Engineering, 18 (1), 240, 2017 [In Polish]. DOI: $10.12912 / 23920629 / 68307$.

20. RODGERS K.M., UDESKY J.O., RUDEL R.A. Environmental chemicals and breast cancer: An updated review of epidemiological literature informed by biological mechanisms. Environmental Research, 160, 152, 2018.
21. DZIUBANEK G., MARCHWIŃSKA-WYRWAŁ E., ĆWIELĄG-DRABEK M., SPYCHAŁA A., RUSIN M., PIEKUT A., HAJOK I. Preliminary study of possible relationships between exposure to PCDD/Fs and dl-PCBs in ambient air and the length of life of people. Science of the Total Environment, 598, 129, 2017. 
